\title{
Micronutrients and ageing: intakes and requirements
}

\author{
Marie-Jeanne Richard* and Anne-Marie Roussel \\ LBSO, Biochimie C, Hopital Albert Michallon, BP217 X, 38043 Grenoble Cedex 09, France
}

\begin{abstract}
Ageing (and related diseases) may be described as a process which results from impaired immunological, genetic, neurological or endocrinological functions. Oxidative mechanisms may play an important role in the ageing process. It is important, therefore, to emphasize the relationship between health and nutrition in the elderly, particularly with regard to antioxidant micronutrient requirements. Indeed, accelerated ageing may be related to a deficit in the intakes of antioxidant vitamins (tocopherols, carotenoids and vitamin C) and trace elements ( $\mathrm{Zn}$ and Se), as well as to an impaired adaptative mechanism against oxidative stress. Physiological modifications occurring during the lifetime and environmental influences are significant factors contributing to the impairment of micronutrient status, and these factors have to be considered when defining the specific requirements of the elderly. For Fe there is no evidence of benefit of supplementation in healthy subjects, but in the present state of knowledge combined supplementation, including $\mathrm{Zn}$, Se, vitamins $\mathrm{C}$ and $\mathrm{E}$ and carotenoids, could be the best way to prevent accelerated ageing and reduce the risk of several common age-related diseases.
\end{abstract}

\section{Résumé}

\begin{abstract}
De nombreuses théories (immunologique, génétique et neuroendocrinologique) ont été proposées pour expliquer les processus de vieillissement et les pathologies qui s'y rapportent. Les mécanismes oxydatifs pourraient contribuer à ces processus et plus particulièrement à leur accélération. La théorie radicalaire repose sur une modification avec l'âge du rapport prooxydants ou antioxydants dû à une majoration des processus oxydatifs accompagnés d'une diminution des systèmes de défense subséquentes à une carence en un ou plusieurs micronutriments antioxydants. Les modifications physiologiques qui accompagnent le vieillisement et une alimentation sélective contribuent aux modifications d'apport et d'absorption des micronutriments. Ces altérations sont accentuées lors de pathologies chroniques. Il n'existe pas de réel consensus sur les recommandations d'apports en oligoéléments adaptés au sujet âgé. Néanmoins les études récentes montrent qu'une association zinc, sélénium, vitamines antioxydantes (vitamines A et $\mathrm{E}$ et caroténoïdes) pourrait être le moyen le plus efficace de lutte contre les pathologies du grand âge et également de prévention du vieillissement accéléré.
\end{abstract}

\section{Ageing: Antioxidants: Micronutrients}

The elderly are a rapidly growing segment of the population, in both developed and developing countries. Thus, the maintenance of a healthy mental and physical state in the elderly appears to be one of the crucial public health challenges for the future. Since numerous clinical and epidemiological studies have confirmed the close relationship between health and nutrition, many reports have aimed to define specific nutrient requirements for ageing individuals. It is important, therefore, to emphasize the relationship between health and nutrition in the elderly, particularly regarding the possible link between nutrition and chronic diseases.

For micronutrients (vitamins and trace elements), requirements and recommended dietary allowances are far from being well established (Mertz, 1990; Harman, 1995). In the present paper we will discuss the influence of antioxidant micronutrients with respect to recent data involving vitamins (tocopherols, carotenoids and vitamin $\mathrm{C}$ ) and trace elements $(\mathrm{Zn}, \mathrm{Se}, \mathrm{Mn}$ and $\mathrm{Cu})$ in cellular antioxidant defences and protection against accelerated ageing processes. 


\section{Micronutrients and the ageing process}

Ageing (and related diseases) may be described as a process which results from impaired immunological, genetic, neurological, endocrinological or antioxidant functions. The free radical theory of ageing (Sohal, 1993; Knight, 1995) suggests an age-related imbalance between pro-oxidant and antioxidant equilibrium, associated with a potential decrease in antioxidant defences. In animals, several workers have shown an inverse relationship between lifespan and the increased production of reactive oxygen species (see Cutler, 1985). Mitochondrial and nuclear DNA modifications were described in old animals. It has been shown in vitro that oxidative stress, administered at sublethal levels, led to genomic alterations and accelerated cellular ageing (Toussaint et al. 1998). In elderly subjects, especially in institutionalized patients, lipoperoxidation (monitored using indirect variables) is enhanced (Tolonen et al. 1988; Monget et al. 1996a; Coudray et al. 1997). Data concerning the relationship between age and DNA oxidation are not yet available from large-scale epidemiological studies, but in limited groups of elderly subjects we have observed a higher level of oxidized bases than in younger adults (Piperakis et al. 1998).

Findings relating to modifications in antioxidant defences in the elderly remain controversial. The discrepancy in the data could be due to the difficulties in defining appropriate population samples that are representative of the various strata of the elderly. How should 'elderly' be defined? A combination of lifestyle, nutritional habits, incidence of diseases and the ageing process itself should be considered. Nevertheless many authors have reported that elderly individuals have lowered $\mathrm{Cu}-\mathrm{Zn}$ superoxide dismutase (EC 1.15.1.1), catalase (EC 1.11.1.6) and GSH peroxidase (EC 1.11.1.9) activities in erythrocytes (see Ceballos-Picot et al. 1992). In France, we recently observed that modifications in antioxidant defences were significantly more important in institutionalized elderly individuals than in healthy free-living elderly individuals (Monget et al. 1996b; Schmuck et al. 1996). In fact, institutionalized individuals should receive particular care with respect to their antioxidant status.

\section{In ageing the changes in antioxidant defences might be due to a deficit of micronutrient intakes and/or might be related also to an impaired adaptive mechanism against oxidative stress}

Selenium. Several lines of evidence have shown that Se plays a key role in protecting cells against free radical attack. This powerful property is mainly due to its antioxidant effect as the constitutive trace element of the active site of GSH peroxidase (Richard et al. 1997) and as a limiting factor for the synthesis of this enzyme. Se can also modulate the immune system (MacKenzie et al. 1998), since in combination with vitamin $\mathrm{E}$ Se acts in protecting immunocompetent cells. Se also has a role in in the detoxification of heavy metals $(\mathrm{Hg}, \mathrm{Cd}$ and $\mathrm{Pb})$ and xenobiotics. This function offers an interesting field of action in elderly patients on multiple medication. Recently reported beneficial effects of antioxidant supplementation on clinical or biological variables suggested a deficient functional status in the elderly (Monget et al. 1996a,b; Girodon et al. 1997a,b).

Zinc. Zn forms part of numerous proteins and plays a key role in many metabolic reactions (Favier, 1994). The role of $\mathrm{Zn}$ as a biological antioxidant is complex (Bray \& Bettger, 1990) and its influence on the ageing process is not completely understood. $\mathrm{Zn}$ is a component of antioxidant metalloenzymes ( $\mathrm{Cu}-\mathrm{Zn}$ superoxide dismutase) and metallothioneins. $\mathrm{Cu}-\mathrm{Zn}$ superoxide dismutase activity is regulated by $\mathrm{Cu}$ intake (Hassan, 1988), but $\mathrm{Zn}$ plays a structural role in the maintenance of enzyme integrity (Coudray et al. 1992). Metallothioneins are low-molecular-weight proteins rich in cysteine whose main function is to transport metals (Bremner \& Davies, 1975), but which can also detoxify reactive oxygen species (Rossman \& Goncharoua, 1998). $\mathrm{Zn}$, by competition with other transition metals, protects $\mathrm{SH}$ groups from oxidation, and in vitro might slow down oxidative damage to $\mathrm{SH}$ groups. By preventing proteins from oxidation, $\mathrm{Zn}$ could contribute to $\mathrm{SH}$ group stabilization, and thus might influence transcription factors such as p53 (Verhaegh et al. 1998). Zn also functions as a cofactor for enzymes of nucleic acid catabolism (endonuclease and caspase; Perry et al. 1997). As described recently, $\mathrm{Zn}$ depletion results in cellular death by apoptosis (Parat et al. 1997). In isolated activated neutrophils (Nakamura et al. 1987) Zn would also decrease free radical production, leading to a potential negative effect on phagocytosis when inadequate $\mathrm{Zn}$ treatment is administered.

Copper. The role of $\mathrm{Cu}$ in oxidative stress remains highly controversial, since $\mathrm{Cu}$ acts both as an antioxidant and as a pro-oxidant. $\mathrm{Cu}$ ions are indeed pro-oxidants in vitro or when body $\mathrm{Cu}$ stores are very high. In contrast, $\mathrm{Cu}$ as an essential constituent of superoxide dismutase or as ferroxidase $(E C$ 1.16.3.1) in caeruloplasmin acts as an antioxidant.

Is the importance of $\mathrm{Cu}$ deficiency, as for $\mathrm{Zn}$ or $\mathrm{Se}$, related to the antioxidant properties of this trace element? What is the incidence of deficient status in the elderly? Further large-scale epidemiological studies and complementary intervention studies are needed to demonstrate functional deficiencies in the elderly (Schmuck et al. 1996). Nevertheless, a revised standpoint should be considered with respect to the possible cardiovascular risk associated with $\mathrm{Cu}$ deficiency.

Iron. In free-living healthy elderly individuals, $\mathrm{Fe}$ deficiency does not appear to be a major problem (Johnson et al. 1994). Fe requirements are lower in older subjects than in younger adults, especially in post-menopausal women. In individuals over 70 years old, although haemoglobin levels can be lowered, body weight: blood mass remains stable or slightly lowered. The prevalence of $\mathrm{Fe}$ deficiency and anaemia (following WHO criteria) is not high in healthy elderly subjects (Kikerby et al. 1991). Thus, Fe, a deficiency of which poses crucial problems in young women, should be considered in a totally different way in older populations.

It has been reported recently that excess Fe has a potential pro-oxidant effect. Free $\mathrm{Fe}$ is indeed implicated in oxidative damage. An inverse relationship between high Fe stores and the risk of coronary disease has been demonstrated 
(Ascherio et al. 1994). The risk of cardiovascular diseases has been related to high dietary intakes of $\mathrm{Fe}$, and excess $\mathrm{Fe}$ has been reported to have a role in carcinogenesis (Nelson et al. 1994). More recently, it was suggested that excess Fe could have a potential role in Alzheimer's disease (Smith et al. 1997). Thus, these findings suggest that excess $\mathrm{Fe}$ could result in a number of deleterious effects and accelerated ageing.

Vitamins. Some vitamins, complementary with antioxidant enzymes and thiol groups, play an antioxidant role in lipid (carotenoids, tocopherols) or aqueous mediums (vitamin C). They are particularly efficient against organic peroxides and singlet oxygen (Chow, 1991; Taylor Maine, 1996).

However, as observed for trace elements, an excess of these vitamins can lead to adverse effects. In vitro, vitamin $\mathrm{C}$ is a pro-oxidant when free metals are present (Podmore et al. 1998). Supplementation with high doses of $\beta$-carotene (five times the nutritional requirement) had an unexpected effect in smokers, and led to an increase incidence of lung cancers (The Alpha-Tocopherol, Beta Carotene Cancer Prevention Study Group, 1994).

\section{Antioxidant micronutrient status in the elderly}

Data on the relationship between age and micronutrient status are still controversial (Favier, 1994). In studies focusing on $\mathrm{Zn}$, the findings varied depending on the variables investigated. However, there appeared to be an inverse correlation between plasma $\mathrm{Zn}$ and age (Hercberg et al. 1991). Our study, which measured the $\mathrm{Zn}$ pool exchange in elderly hospitalized patients, confirmed decreased storage of $\mathrm{Zn}$ in elderly patients. The deficits of $\mathrm{Zn}$ seemed to be more related to hospitalization and associated diseases than to age itself (Schmuck et al. 1996).

$\mathrm{Cu}$ status does not appear to be modified or increased with ageing. In the elderly, $\mathrm{Cu}: \mathrm{Zn}$ tends to increase. This increase could lead to a decreased availability of $\mathrm{Zn}$ by stimulating the synthesis of metallothioneins.

Se status does not seem to be modified in healthy subjects until the age of 75 years (Neve, 1989; Olivieri, 1994), when the Se status is lowered. Using stable isotopes, a recent study showed a relationship between the decrease in the size of the Se pool and the incidence of associated diseases (Ducros et al. 1997).

For vitamins, most studies have failed to show a significant relationship between age and plasma retinol levels (Succari \& Cals, 1998). Data focusing on vitamin E are difficult to discuss if they do not consider lipid or cholesterol levels. Indeed, when vitamin E: cholesterol was measured, no effect of age on vitamin E status was observed (Heseker \& Schneider, 1994). For vitamin C, the main observation appears to be an inverse correlation between age and blood levels. Recently, Heseker \& Schneider (1994) reported a lower level of plasma vitamin $\mathrm{C}$ in older men compared with younger controls with the same dietary intakes of vitamin C. Data on carotenoids are scarce, but a tendency to an increased level of plasma carotenoids with age has been reported in free-living subjects (Hallfrish et al. 1994), but we were unable to confirm these findings (Berr et al. 1998).

\section{Micronutrient requirements in the elderly}

Physiological modifications occurring during the lifetime and environmental influences are significant factors contributing to the impairment of trace element status in the elderly. Physiological modifications of the gastrointestinal tract, decreased pancreatic function, frequent lesions caused by gastritis, intestinal $\mathrm{pH}$ modifications resulting in decreased absorption, loss of appetite and selection of foods may be responsible for the deficiency. However, the Euronut Seneca Study (1992) reported a relatively good nutritional status in free-living European elderly subjects. In contrast, in hospitalized subjects an important incidence of deficiencies and malnutrition has been described by many authors (Bunker \& Clayton, 1989; Schmuck et al. 1996; Coudray et al. 1997; Table 1). In the healthy elderly an efficient adaptive mechanism to these modifications occurs for some elements. However, the presence of chronic diseases significantly affects absorption and bioavailability of trace elements, mainly as a consequence of drug treatment (anti-acids, diuretics, antibiotics and steroids). In elderly individuals, as in younger adults, the concept of risk groups must be considered with respect to environmental factors (loneliness and low socio-economic level) or depression, functional impotencies and hypertension. The risk increases during long-term hospitalization or when physical or mental stress suddenly affects the potential mechanism of adaptation. Taking into consideration the physiological modifications associated with ageing, the incidence of chronic disease and the decreased intakes, the Standing Committee on Dietary Reference Intakes (World Health Organization/Food and Agriculture Organization/ International Atomic Energy Authority, 1996) suggested the adoption of new age-ranges (51-70, 71-80 and over 81 years) in defining the specific requirements of the elderly.

\section{Recommended dietary allowances}

Few studies focus on recommended dietary allowances (RDA) for micronutrients in the elderly (Guigoz, 1994; Table 2). Where they exist, they are extrapolated from RDA for younger adults. In France, the recommended nutrient intakes (apports nutritionnels conseillés; Dupin et al. 1992) relate to subjects aged 65 years and more with a mean

Table 1. Trace element intakes in the healthy elderly (From Bunker \& Clayton, 1989)

\begin{tabular}{|c|c|c|c|c|}
\hline & $\begin{array}{l}\text { Healthy free- } \\
\text { living elderly }\end{array}$ & $\begin{array}{l}\text { Long-term } \\
\text { institutionalized } \\
\text { elderly }\end{array}$ & RDA & ANC \\
\hline $\mathrm{Zn}(\mathrm{mg} / \mathrm{d})$ & $9 \cdot 0$ & 5.9 & $12-15$ & 12 \\
\hline $\mathrm{Cu}(\mathrm{mg} / \mathrm{d})$ & 1.2 & $0.7-1.0$ & $1 \cdot 5-3^{*}$ & $2 \cdot 5^{*}$ \\
\hline $\mathrm{Fe}(\mathrm{mg} / \mathrm{d})$ & 9.2 & 8.9 & 10 & 10 \\
\hline $\mathrm{Mn}(\mathrm{mg} / \mathrm{d})$ & $5 \cdot 3$ & 4.0 & $3 \cdot 5^{*}$ & 4 \\
\hline $\operatorname{Cr}(\mu \mathrm{g} / \mathrm{d})$ & $22 \cdot 9$ & $26 \cdot 8$ & $50-200^{*}$ & - \\
\hline $\operatorname{Se}(\mu \mathrm{g} / \mathrm{d})$ & $64 \cdot 7$ & 37.5 & $55-75$ & 70 \\
\hline
\end{tabular}

RDA, recommended dietary allowances (National Research Council, 1989); ANC, apports nutritionnels conseillés (recommended nutrient intakes; Dupin et al. 1992).

* Estimated safe and adequate daily intake (National Research Council, 1989). 
Table 2. National recommended nutrient intakes for the elderly (From Guigoz, 1994)

\begin{tabular}{|c|c|c|c|c|c|c|}
\hline \multirow[b]{2}{*}{ Age (years) } & \multirow{2}{*}{$\begin{array}{c}\text { USA } \\
\text { RDA } \\
>51\end{array}$} & \multirow{2}{*}{$\begin{array}{c}\text { UK } \\
\text { DRV } \\
>50\end{array}$} & \multirow{2}{*}{$\begin{array}{c}\text { Germany } \\
\text { ENZ } \\
>65\end{array}$} & \multicolumn{2}{|c|}{$\begin{array}{c}\text { Canada } \\
\text { RNI (ANR) }\end{array}$} & \multirow{2}{*}{$\begin{array}{c}\text { France } \\
\text { ANC }\end{array}$} \\
\hline & & & & $50-74$ & $>75$ & \\
\hline Energy (MJ) & $8 \cdot 0-9.6$ & $8 \cdot 0-9 \cdot 7$ & $7 \cdot 1-8 \cdot 0$ & $7 \cdot 5-9.6$ & $7 \cdot 1-8 \cdot 3$ & $6 \cdot 3-8 \cdot 8$ \\
\hline $\mathrm{Fe}(\mathrm{mg} / \mathrm{d})$ & 10 & 8.7 & 10 & 8.9 & 8.9 & 10 \\
\hline $\mathrm{Zn}(\mathrm{mg} / \mathrm{d})$ & $12-15$ & $7 \cdot 0-9.5$ & $12-15$ & $9-12$ & $9-12$ & 12 \\
\hline $\operatorname{Se}(\mu \mathrm{g} / \mathrm{d})$ & $55-75$ & $60-75$ & $20-100$ & 50 & 50 & 70 \\
\hline $\mathrm{Cu}(\mathrm{mg} / \mathrm{d})$ & $1.5-3.0$ & $1-2$ & $1.5-3.0$ & - & - & $2-5$ \\
\hline $\mathrm{Mn}^{*}(\mathrm{mg} / \mathrm{d})$ & $2 \cdot 0-5 \cdot 0$ & - & $2 \cdot 0-5 \cdot 0$ & $3-5$ & $3-5$ & 4 \\
\hline $\operatorname{Cr}(\mu \mathrm{g} / \mathrm{d})$ & $50-200$ & - & 50-200 & - & 125 & - \\
\hline Vitamin E (mg/d) & $8-10$ & - & - & - & - & 12 \\
\hline Vitamin C (mg/d) & 60 & - & - & - & - & 80 \\
\hline Carotenoids (mg/d) & - & - & - & - & - & $4-5$ \\
\hline
\end{tabular}

RDA, recommended dietary allowances; DRV, dietary reference value; ENZ, empfehlungen für die nährstoffzufuhr; ANR, apports nutritionnels recommandés; RNI, recommended nutrient intake; ANC, apports nutritionnels conseillés.

* Estimated safe and adequate daily intakes.

body weight of $60 \mathrm{~kg}$. In the USA, the RDA (National Research Council, 1989) relate to adults over 51 years old. For $\mathrm{Cu}, \mathrm{Mn}$ and $\mathrm{Cr}$ only estimated safe and adequate dietary intakes are proposed. Recommendations give information only on the range of intakes estimated to fulfil the needs of a group or a general population. Thus, recommended values are above the minimal requirements and aim to fulfil the needs of $95 \%$ of individuals; so, these recommendations are typically to be considered with caution for the elderly, and requirements largely depend on individual factors. For trace elements, new proposals from World Health Organization/Food and Agriculture Organization/International Atomic Energy Authority (1996) or the US Committee on Dietary Intakes (RDA workshop, 1996) suggested revising the RDA. What should RDA represent? Should they aim only to prevent deficiency, and should they be defined just in terms of safety? Or should they aim to maintain the nutrient status (even if minimal) in order to prevent a decrease in biological variables? Or should they aim to cause optimal and protective effects against age-related diseases?

\section{Supplementation}

Several Se supplementation trials conducted in elderly subjects (Bortoli et al. 1991; Peretz et al. 1991; Simonoff et al. 1992; Monget et al. 1996a), using 66-125 $\mu \mathrm{g} / \mathrm{d}$ in an organic or inorganic form, combined (or not) with other antioxidant micronutrients, had beneficial effects on status, immunity, lipoperoxidation and erythrocyte sensitivity to haemolysis (Table 3). Moreover, epidemiological data highlighted the key role of $\mathrm{Se}$ in protecting against ageassociated diseases (cardiovascular disease and cancers). Thus it seems that an intake of 50-100 $\mu \mathrm{g}$ Se/d should be achieved in elderly subjects with subclinical Se deficiency.

The effects of $\mathrm{Zn}$ supplementation on immunity in the elderly gave interesting results (Table 4); with doses from 15 to $100 \mathrm{mg} / \mathrm{d}$, beneficial effects were observed. The supplement was often a combined mixture of trace elements and vitamins, thus the specific effect of $\mathrm{Zn}$ was difficult to estimate. However, the efficiency of combined supplementation underlines the complementary effect of such a mixture. Recently, using combined supplementation for 6 months in very old subjects ( $>80$ years old), we observed a decrease in lipoperoxidation (Monget et al. 1996b) and erythrocyte-induced haemolysis (Girodon et al. 1997a).

The MinVitAox Study (Monget et al. 1996a,b; Girodon et al. 1997a,b) clearly demonstrated the incidence of multiple deficiencies in the hospitalized elderly, and suggested that combined supplementation would be beneficial in this population. In this study, the incidence of infections was significantly lowered in the supplemented group.

\section{Conclusions}

Micronutrient intakes and status are frequently deficient in elderly subjects, resulting in age-related oxidative diseases. In view of the relationship between nutrition and health in the elderly, more attention should be devoted to fulfilling the requirements of the elderly; revised dietary allowances

Table 3. Selenium supplementation in the elderly

\begin{tabular}{|c|c|c|c|c|c|c|}
\hline Reference & Supplementation & Duration (months) & Plasma Se & Erythrocyte GPx & TBARS & Immunity \\
\hline $\begin{array}{l}\text { Peretz et al. } \\
\quad(1991)\end{array}$ & $100 \mu \mathrm{g}$ & 6 & $\pi$ & $\pi$ & NS & Restoration \\
\hline $\begin{array}{l}\text { Bortoli et al. } \\
\quad(1991)\end{array}$ & $\begin{array}{c}66 \mu \mathrm{g} \text { selenite }+20 \mathrm{mg} \\
\text { vitamin } \mathrm{E}\end{array}$ & 1 & $\pi$ & $\pi$ & $y$ & \\
\hline $\begin{array}{l}\text { Simonoff et al. } \\
(1992)\end{array}$ & $120 \mu \mathrm{g}$ selenite & 1 & $\pi$ & ND & $y$ & \\
\hline $\begin{array}{l}\text { Monget et al. } \\
\quad(1996 a)\end{array}$ & $\begin{array}{l}100 \mu \mathrm{g} \text { selenite }+ \text { anti- } \\
\text { oxidant micronutrients }\end{array}$ & 12 & $\pi$ & $\pi$ & NS & $\pi \mid \mathrm{L}-1$ \\
\hline
\end{tabular}

GPx, GSH peroxidase (EC 1.11.1.9); TBARS, thiobarbituric acid-reactive substances; IL-1, interleukin 1; $\boldsymbol{\pi}$, significant increase; $\mathbf{\searrow}$, significant decrease; ND, not determined. 
Table 4. Zinc supplementation and immune functions in the elderly

\begin{tabular}{lcc}
\hline Reference & Supplement & Response \\
\hline Boukaiba et al. (1993) & $20 \mathrm{mg}$ & $\begin{array}{c}\text { Restoration of thymulin } \\
\text { activity }\end{array}$ \\
$\begin{array}{l}\text { Bogden et al. (1994) } \\
15 \mathrm{mg}+\text { other } \\
\text { trace elements }\end{array}$ & $\begin{array}{c}\text { Increased response to } \\
\text { cutaneous tests } \\
\text { (DHST) }\end{array}$ \\
$\begin{array}{ccc}\text { Galan et al. (1994) } & \text { IL-1 increase } \\
\text { antioxidants }\end{array}$ \\
\hline
\end{tabular}

DHST, delayed-type hypersensitivity test; IL-1, interleukin 1.

Table 5. Revised dietary allowances and requirements for trace elements in the elderly

\begin{tabular}{lcc}
\hline Group ... & $\begin{array}{c}>75 \text { years, hospitalized, } \\
\text { dependant, chronic pathologies }\end{array}$ & $\begin{array}{c}\text { Healthy elderly } \\
\text { people }\end{array}$ \\
\hline $\mathrm{Zn}(\mathrm{mg} / \mathrm{d})$ & $20-30$ & 10 \\
$\mathrm{Se}(\mu \mathrm{g} / \mathrm{d})$ & $70-100$ & $50-70$ \\
$\mathrm{Cr}(\mu \mathrm{g} / \mathrm{d})$ & $100-200$ & $50-100$ \\
$\mathrm{Fe}$ & Dependent on degree of anaemia & None \\
\hline
\end{tabular}

are shown in Table 5. There is now good evidence that appropriate supplementation can reduce the risk of several common age-related diseases. Combined supplementation with antioxidant trace elements and vitamins could be the best way to prevent accelerated ageing and age-related diseases. For Fe, there is no evidence of the benefit of supplementation in healthy elderly subjects, but according to our present state of knowledge, protection should be optimal using supplements which contain $\mathrm{Zn}$, Se, vitamin C, E and carotenoids.

\section{References}

Ascherio A, Willett WC, Rimm EB, Giovannucci EL \& Stampfer M (1994) Dietary iron intake and risk of coronary disease among men. Circulation 89, 969-974.

Berr C, Richard MJ, Roussel AM, Bonithon-Kopp C \& The EVA Study Group (1998) Systemic oxidative stress and cognitive performance in the population-based EVA study. Free Radicals in Biology and Medicine 24, 1202-1208.

Bogden JD, Bendich A \& Kemp FW (1994) Daily micronutrient supplements enhance delayed type hypersensitivity skin test responses in older people. American Journal of Clinical Nutrition 60, 437-447.

Bortoli A, Fazzini G, Marchioni M, Mello F, Grugiolo R \& Martelli F (1991) Selenium status and effect of selenium supplementation in a group of elderly women. Journal of Trace Elements and Electrolytes in Health and Disease 5, 19-21.

Boukaiba N, Flament C \& Acher S (1993) A physiological amount of zinc supplementation effects on nutritional, lipid, and thymic status in an elderly population. American Journal of Clinical Nutrition 57, 566-572.

Bray TM \& Bettger WJ (1990) The physiological role of zinc as an antioxidant. Free Radicals in Biology and Medicine 8, 281-291.

Bremner I \& Davies NT (1975) The induction of metallothionein in rat liver by zinc injection and restriction of food intake. Biochemical Journal 149, 733-738.

Bunker VW \& Clayton BE (1989) Research review. Studies in the nutrition of elderly people with particular reference to essential trace elements. Age and Ageing 18, 422-429.
Ceballos-Picot I, Trivier JM, Nicole A, Sinet PM \& Thevenin M (1992) Age correlated modifications of copper-zinc superoxide dismutase and glutathione related enzymes activities in human erythrocytes. Clinical Chemistry 38, 66-70.

Chow CK (1991) Vitamin E and oxidative stress. Free Radicals in Biology and Medicine 11, 215-232.

Coudray C, Richard MJ, Laporte F, Faure P, Roussel AM \& Favier A (1992) Superoxide dismutase activity and zinc status: a study in animals and man. Journal of Nutritional Medicine 3, 13-26.

Coudray C, Roussel AM, Mainard F, Arnaud J \& Favier A (1997) Lipid peroxidation level and micronutrient status in a pre-aging population: Correlation with chronic disease prevalence in a French epidemiological study. Journal of the American College of Nutrition 16, 584-591.

Cutler RG (1985) Antioxidants and longevity of mammalian species. In Molecular Biology of Aging, pp. 15-73 [AD Woodhead, AD Blackette and A Hollaender, editors]. New York: Plenum Press.

Ducros V, Faure P, Ferry M, Couzy F, Biajoux I \& Favier A (1997) The sizes of the exchangeable pools of selenium in elderly women and their relation to institutionalization. British Journal of Nutrition 78, 379-396.

Dupin H, Abraham J \& Giachetti I (1992) Apports Nutritionnels Conseillés pour la Population Française (Nutrient Requirements of Adults and Recommended Intakes to Meet these Requirements). 2nd ed. Paris: Technique et Documentation Lavoisier.

Euronut Seneca Investigators (1991) Intakes of vitamins and minerals. European Journal of Clinical Nutrition 45, Suppl. 3, 121-138.

Favier A (1994) Zinc et vieillissement (Zinc and ageing). Age et Nutrition 5, 48-64.

Galan P, Preziosi P, Richard MJ, Monget AL, Arnaud J, Lesourd B, Favier A, Girodon P, Bourgeois CF, Keller H \& Hercberg S (1994) Biological and immunological effects of trace elements and/or vitamin supplementation in the elderly. In Trace Elements and Free Radicals in Oxidative Diseases, pp. 197-222 [A Favier, J Neve and P Faure, editors]. Champaign, IL: AOCS Press.

Girodon F, Blache D, Monget AL, Lombart M, Brunet P, Arnaud J, Richard MJ \& Galan P (1997a) Effect of a two year supplementation with low doses of antioxidant vitamins and/or minerals in elderly subjects on levels of nutrients and antioxidant defense parameters. Journal of the American College of Nutrition 16, 357-365.

Girodon F, Lombard M, Galan P, Brunet-Lecomte P, Monget AL, Arnaud J, Preziosi P \& Hercberg S (1997b) Effect of micronutrient supplementation on infection in institutionalized elderly subjects: a controlled trial. Annals of Nutrition and Metabolism 41, 98-107.

Guigoz Y (1994) Recommended daily allowances (RDA) for the free-living elderly. Fact and Research in Gerontology, Suppl. 2, $113-143$.

Hallfrish J, Muller DC \& Singh VN (1994) Vitamin A and E intakes and plasma concentrations of retinol, $\beta$-carotene, and $\alpha$-tocopherol in men and women of the Baltimore longitudinal study of aging. American Journal of Clinical Nutrition 60, 176182.

Harman D (1995) Role of antioxidant nutrients in aging: an overview. Age 18, 51-62.

Hassan HM (1988) Biosynthesis and regulation of superoxide dismutases. Free Radicals in Biology and Medicine 5, 377-385.

Hercberg S, Preziosi P, Galan P, Deheeger M, Papoz L \& Dupin H (1991) Apports nutritionnels d'un échantillon représentatif de la population du Val de Marne: III Les apports en minéraux et vitamines (Nutrient intakes of a representative sample of the population of Val de Marne: III Mineral and vitamin intakes). Revue de l'Epidemiologie et de la Santé Publique 39, 245-261. 
Heseker H \& Schneider R (1994) Requirements and supply of vitamin $\mathrm{C}, \mathrm{E}, \beta$-carotene for elderly men and women. European Journal of Clinical Nutrition 48, 118-127.

Johnson MA, Fisher JG, Bowman BA \& Gunter EW (1994) Iron nutriture in elderly individuals. FASEB Journal 8, 609-621.

Kikerby OJ, Fossum S \& Riscone C (1991) Anaemia in elderly patients. Scandinavian Journal of Primary Health Care 9, 167171.

Knight JA (1995) The process and theory of aging. Annals of Clinical and Laboratory Science 25, 11-12.

MacKenzie R, Rafferty T \& Beckett G (1998) Selenium: an essential element for immune function. Immunology Today 19, 342-345.

Mertz W (1990) The role of trace elements in the aging process. Progress in Clinical and Biological Research 326, 229-240.

Monget AL, Galan P, Preziosi P, Keller H, Bourgeois C, Arnaud J, Favier A \& Hercberg S (1996a) Micronutrient status in elderly people. Geriatrie/Min VitAox Network. International Journal of Vitamin and Nutrition Research 66, 71-76.

Monget AL, Richard MJ, Cournot MP, Arnaud J, Galan P, Preziosi P, Herbeth B, Favier A, Hercberg S \& The Geriatrie/MinVitAox Network (1996b) Effect of 6 month supplementation with different combinations of an association of antioxidant nutrients on biochemical parameters and markers of the antioxidant defence system in the elderly. European Journal of Clinical Nutrition 50, 443-449.

Nakamura T, Shiraishi N \& Aono K (1987) Effects of in vitro and in vivo supplementation with zinc on superoxide anion production in leucocytes. Physiological Chemistry and Physics and Medical NMR 19, 147-151.

National Research Council (1989) Recommended Dietary Allowances, 10th ed. Washington, DC: National Academy Press.

Nelson RL, Davis FG, Sutter E, Sobin LH, Kikendhal JW \& Bowen P (1994) Body iron stores and risk of colonic neoplasia. Journal of the National Cancer Institute 86, 455-466.

Neve J (1989) Biological functions of selenium. In Selenium in Medicine and Biology, pp. 97-111 [J Neve and A Favier, editors]. Berlin: Walter de Gruyter.

Neve J, Vertongen F, Peretz A \& Carpentier YA (1989) Valeurs usuelles du sélénium et de la glutathion peroxydase dans une population belge (Everyday importance of selenium and glutathione peroxidase in the Belgian population). Annales de Biologie Clinique 47, 138-143.

Olivieri O, Stanziali AM, Girelli D, Trevisan MT, Guarini P, Terzi M, Caffi S, Fontana F, Casaril M, Ferrari S \& Corrocher R (1994) Selenium status, fatty acids, vitamin $\mathrm{A}$ and $\mathrm{E}$, and aging: the Nove Study. American Journal of Clinical Nutrition 60, 510517.

Parat MO, Richard MJ, Pollet S, Hadjur C, Favier A \& Beani JC (1997) Zinc and DNA fragmentation in keratinocyte apoptosis: its inhibitory effect in UVB irradiated cells. Photochemistry and Photobiology 37, 101-106.

Peretz A, Neve J, Desmedt J, Duchateau J, Dramaix M \& Famaey JP (1991) Lymphocyte response is enhanced by supplementation of elderly people with selenium-enriched yeast. American Journal of Clinical Nutrition 53, 1323-1328.

Perry D, Smyth MJ, Stennicke HR, Salvesen GS, Duriez P, Poirier G \& Hannun Y (1997) Zinc is a potent inhibitor of the apoptotic protease, caspase-3. A novel target for zinc in the inhibition of apoptosis. Journal of Biological Chemistry 271, 18530-18533.
Piperakis SM, Visvardis EE, Sagnou M \& Tassiou AM (1998) Effects of smoking and aging on oxidative DNA damage of human lymphocytes. Carcinogenesis 19, 695-698.

Podmore I, Griffith H, Herbert K, Mistry N, Mistry P \& Lunec J (1998) Vitamin C exhibits pro-oxidant capacities. Nature 392, 558.

RDA Workshop (1996) New approaches, end points and paradigms for RDAs of mineral elements. Journal of Nutrition 126, Suppl. 2299-2459

Richard MJ, Belleville F, Chalas J, Ceballos-Picot I, Vitoux D, Boyer MJ, Chaudiere J \& Favier A (1997) Les glutathion peroxydases: intérêt de leur dosage en biologie clinique (Glutathione peroxidases: value of their determination in clinical biology). Annales de Biologie Clinique 55, 195-207.

Rossman T \& Goncharova E (1998) Spontaneous mutagenesis in mammalian cells is caused mainly by oxidative events and can be blocked by antioxidants and metallothionein. Mutation Research 402, 103-110.

Schmuck A, Roussel AM, Arnaud J, Ducros V, Favier A \& Franco A (1996) Analyzed dietary intakes, plasma concentrations of zinc, copper, and selenium and related metalloenzyme activities in hospitalized elderly women. Journal of the American College of Nutrition 15, 462-470.

Simonoff M, Segeant C, Garnier N, Moretto P, Llabador Y, Simonoff C \& Conri C (1992) Antioxidant status (Se, Vit A, E) and aging. In Free Radicals and Aging, pp. 368-397 [I Emerit and B Chance, editors] Basel: Birhaüser Verlag.

Smith M, Harris P, Sayre L \& Perry G (1997) Iron accumulation in Alzheimer disease is a source of redox-generated free radicals. Proceedings of the National Academy of Sciences USA 94, 98669868.

Sohal RS (1993) The free radical hypothesis of aging: an appraisal of the current status. Aging, Clinical and Experimental Research 5, 3-17.

Succari M \& Cals MJ (1998) Influence du vieillissement normal et pathologique sur le statut vitaminique (Influence of normal and pathological ageing on vitamin status). In Le Statut Vitaminique: Physiopathologie, Exploration Biologique et Interêt Clinique. (Vitamin Status: Physiopathology, Biological Investigation and Clinical Significance), pp. 354-370 [G Le Moel, A SaverotDauvergne, T Gousson and JL Guéant, editors]. Cachan, France: Editions Médicales Internationales.

Taylor Maine S (1996) Beta carotene, carotenoids and disease prevention in humans. FASEB Journal 10, 690-701.

The Alpha-Tocopherol, Beta Carotene Cancer Prevention Study Group (1994) The effect of vitamin E and beta carotene on the incidence of lung cancer and other cancers in male smokers. New England Journal of Medicine 330, 1029-1035.

Tolonen M, Halme M \& Sarna S (1988) Vitamin E and selenium supplementation in geriatric patients: a double-blind preliminary clinical trial. Biological Trace Element Research 7, 161-177.

Toussaint O, Raes M, Michiels C \& Remacle J (1998) La réponse des cellules aux stress: relation avec le processus de vieillissement et la pathologie (The response of cells to stress: relationship to the ageing process and the pathology). Medical Science 14, 622-635.

Verhaegh G, Parta MO, Richard MJ \& Hainaut P (1998) Modulation of p53 protein conformation and DNA-binding activity by intracellular chelation of zinc. Molecular Carcinogenesis 21, 205-214.

World Health Organization/Food and Agriculture Organization/ International Atomic Energy Authority (1996) Trace Elements in Human Nutrition and Health. Geneva: WHO. 